Louisiana State University

LSU Digital Commons

Faculty Publications

Department of Biological Sciences

8-13-2013

\title{
Enthalpic switch-points and temperature dependencies of DNA binding and nucleotide incorporation by Pol i DNA polymerases
}

Hiromi S. Brown

Louisiana State University

Vince J. Licata

Louisiana State University

Follow this and additional works at: https://digitalcommons.Isu.edu/biosci_pubs

\section{Recommended Citation}

Brown, H., \& Licata, V. (2013). Enthalpic switch-points and temperature dependencies of DNA binding and nucleotide incorporation by Pol i DNA polymerases. Biochimica et Biophysica Acta - Proteins and Proteomics, 1834 (10), 2133-2138. https://doi.org/10.1016/j.bbapap.2013.06.021

This Article is brought to you for free and open access by the Department of Biological Sciences at LSU Digital Commons. It has been accepted for inclusion in Faculty Publications by an authorized administrator of LSU Digital Commons. For more information, please contact ir@lsu.edu. 


\title{
Enthalpic switch-points and temperature dependencies of DNA binding and nucleotide incorporation by Pol I DNA polymerases
}

\author{
Hiromi S. Brown, Vince J. LiCata* \\ Department of Biological Sciences, Louisiana State University, Baton Rouge, LA 70803, USA
}

\section{A R T I C L E I N F O}

\section{Article history:}

Received 1 April 2013

Received in revised form 21 June 2013

Accepted 25 June 2013

Available online 10 July 2013

\section{Keywords:}

Taq polymerase

Klenow

Thermodynamics

Gibbs-Helmholtz

Eyring

DNA replication

\begin{abstract}
A B S T R A C T
This study examines the relationship between the DNA binding thermodynamics and the enzymatic activity of the Klenow and Klentaq Pol I DNA polymerases from Escherichia coli and Thermus aquaticus. Both polymerases bind DNA with nanomolar affinity at temperatures down to at least $5{ }^{\circ} \mathrm{C}$, but have lower than $1 \%$ enzymatic activity at these lower temperatures. For both polymerases it is found that the temperature of onset of significant enzymatic activity corresponds with the temperature where the enthalpy of binding $\left(\Delta \mathrm{H}_{\text {binding }}\right)$ crosses zero $\left(\mathrm{T}_{\mathrm{H}}\right)$ and becomes favorable (negative). This $\mathrm{T}_{\mathrm{H}}$ /activity upshift temperature is $15{ }^{\circ} \mathrm{C}$ for Klenow and $30{ }^{\circ} \mathrm{C}$ for Klentaq. The results indicate that a negative free energy of DNA binding alone is not sufficient to proceed to catalysis, but that the enthalpic versus entropic balance of binding may be a modulator of the temperature dependence of enzymatic function. Analysis of the temperature dependence of the catalytic activity of Klentaq polymerase using expanded Eyring theory yields thermodynamic patterns for $\Delta G^{\ddagger}, \Delta \mathrm{H}^{\ddagger}$, and $\mathrm{T} \Delta \mathrm{S}^{\ddagger}$ that are highly analogous to those commonly observed for direct DNA binding. Eyring analysis also finds a significant $\Delta \mathrm{Cp}^{\ddagger}$ of formation of the activated complex, which in turn indicates that the temperature of maximal activity, after which incorporation rate slows with increasing temperature, will correspond with the temperature where the activation enthalpy $\left(\Delta \mathrm{H}^{\ddagger}\right)$ switches from positive to negative.
\end{abstract}

(c) 2013 Elsevier B.V. All rights reserved.

\section{Introduction}

Primer-template DNA (pt-DNA) binding by a DNA polymerase is the first step of the DNA polymerization cycle. We have previously characterized the thermodynamics of pt-DNA binding with respect to salt and temperature for the Klenow and Klentaq "large fragments" of DNA polymerase I from Escherichia coli and Thermus aquaticus [1,2]. The present study asks the question of how these initial binding thermodynamics are related to or potentially influence the characteristics of the overall enzymatic cycle of the polymerases.

The Pol I DNA polymerases from E. coli and T. aquaticus are both single polypeptide chains comprised of three structure/function domains: a polymerization domain, a proofreading domain (inactive in Taq), and a 5' nuclease domain. Removal of the $5^{\prime}$ nuclease domains yields the Klenow and Klentaq "large fragments" of each polymerase, both of which are fully functional polymerases on their own.

Previous studies of the temperature dependence of DNA binding of the two different polymerases established a variety of different thermodynamic characteristics for the two binding reactions $[1,2]$. Both binding reactions have been shown to display a classic curved Gibbs-Helmholtz plot ( $\Delta \mathrm{G}$ versus temperature), indicative of a significant heat capacity of binding and a strong temperature dependence of both the enthalpy and entropy of binding. Enthalpy-entropy

\footnotetext{
* Corresponding author. Tel.: +1 225578 5233; fax: +1 2255782597.

E-mail address: licata@lsu.edu (V.J. LiCata).
}

compensation is observed for the binding of both polymerases, such that both the $\Delta H$ and the $\Delta S$ progress from positive values at low temperature to negative values at high temperature roughly in parallel. Enthalpy-entropy compensation for protein-DNA interactions and other biomolecular interactions has been recognized, and its meaning debated, for decades (e.g. [3-6]).

In the present study, nucleotide incorporation activity was measured with respect to temperature for both polymerases to characterize the kinetic behavior of the polymerases under a variety of solution conditions. What is somewhat more unusual, however, is that we examine possible connections between the thermodynamics of initial binding of the polymerases and their kinetic behavior. For both polymerases it is observed that the temperature where the $\Delta H$ of DNA binding switches from positive to negative $\left(\mathrm{T}_{\mathrm{H}}\right)$ correlates with the temperature where nucleotide incorporation activity becomes significant $(>1 \%)$. The data suggest that the enthalpy-entropy compensation pattern displayed by polymerase binding may be related to the modulation of enzymatic activity. Eyring analysis of the temperature dependence of polymerization kinetics for Klentaq further suggests a heat capacity change upon formation of the activated complex resulting in a correspondence between the temperature where the activation enthalpy crosses zero and the temperature where the enzymatic activity reaches a maximum and begins to decrease. The findings suggest that temperatures where enthalpy (of binding or of activation) changes sign are possible regulatory points in the control of polymerase activity. 


\section{Materials and methods}

\subsection{Proteins and DNA}

Purification of the proteins has been described previously [7]. M13mp18(+) DNA was purchased from Amersham Pharmacia Biotech/GE Healthcare Life Sciences. E. coli competent strain JM109 from Promega was transformed with M13mp18(+) as described in the company's technical bulletin. The isolated single stranded M13 DNA was annealed with a 63-deoxyribonucleotide oligomer (P63): 5'CCATCCTAATTTACGAGCATGTAGAAACCAATCAATAATCGGCTGTCTTTCC TTATCATTCCA3' (from Integrated DNA Technologies, Inc.) which complements positions 3489-3551 of the single stranded M13 DNA. Equimolar amounts of P63 and M13 DNA were annealed in TE buffer by heating at $95{ }^{\circ} \mathrm{C}$ for $5 \mathrm{~min}$ and gradually returning to room temperature. Use of this specifically primed-M13 nucleotide incorporation system, rather than using "activated" or randomly sheared calf-thymus or salmon sperm DNA as used in most polymerase nucleotide incorporation assays, means that the primer-template junction that the polymerases encounter in the nucleotide incorporation assay is the same as in the previous direct binding assays $[1,2]$.

\subsection{Other materials}

dATP, dTTP, dCTP, and dGTP were purchased from Promega. $\left[\alpha-{ }^{32} \mathrm{P}\right] \mathrm{dATP}(3000 \mathrm{Ci} / \mathrm{mmol})$ was from PerkinElmer. DE81 filters were from Whatman, ScintiVerse BD Cocktail was from Fisher Scientific, and all other reagents were from Sigma Chemical or Fisher Scientific.

\subsection{Nucleotide incorporation assay}

The nucleotide incorporation reaction mixture was composed of $10 \mathrm{nM}$ of annealed P63/M13mer, $200 \mu \mathrm{M}$ each of dTTP, dCTP, and dGTP, $150 \mu \mathrm{M}$ dATP, $100 \mu \mathrm{Ci} / \mathrm{mL}\left[\alpha^{-32} \mathrm{P}\right] \mathrm{dATP}$, and $1 \mu \mathrm{M}$ DNA polymerase in a total volume of $20 \mu \mathrm{L}$. All reactions were initiated by addition of enzyme. The polymerases and the rest of the reaction mixture were separately equilibrated at reaction temperatures for 5 min before addition of enzyme. After timed incubations, reactions were quenched by adding $20 \mu \mathrm{L}$ of $300 \mathrm{mM}$ EDTA. Background measurements, and the zero timepoint, were obtained by replacing the enzyme with the corresponding buffer. Background measurements were insensitive to time of incubation. Each measurement was repeated three times. The incorporation of $\left[\alpha-{ }^{32} \mathrm{P}\right] \mathrm{dATP}$ was measured on DE81 filters as originally described by Bryant et al. [8] with small modifications in the washing steps. The procedure used herein was as follows: $10 \mu \mathrm{L}$ of the quenched reaction mixture was spotted on a DE81 filter. The filters were air-dried, then washed in a buffer containing $300 \mathrm{mM}$ sodium phosphate, pH 7 for $5 \mathrm{~min}$, with gentle swirling every $30 \mathrm{~s}$. The filters were washed 3 times in the washing-buffer followed by a wash with $70 \%$ ethanol. $5 \mathrm{~mL}$ of washing-buffer and $2 \mathrm{~mL}$ of $70 \%$ ethanol per individual DE81 filter disk were used for each wash. The filters were then air dried again, then immersed in $4 \mathrm{~mL}$ of scintillation cocktail. Radioactivity present in DNA was counted with a Packard BioScience Tri-Carb 2900TR Liquid Scintillation Analyzer. In order to determine the amount of dNMP incorporated by the polymerases, background and total radioactivity measurements were carried out. In the total radioactivity measurements, the washing steps were omitted. The total number of nucleotides (nts) incorporated per $10 \mathrm{nM}$ P63/M13mer was calculated with the following equation: \{[sample count (cpm) - background count (cpm)] / total count (cpm) $* 150 \mu \mathrm{M}$ dATP $* 3.07 / 10 \mathrm{nM}$ (concentration of P63/M13mer). The value of 3.07 was calculated using a thymine content for single stranded M13mp18(+) of $32.6 \%$.

\subsection{Temperature dependence of polymerase activity}

The buffers used for temperature dependent nucleotide incorporation assays were the same as those previously used for the temperature dependent primer-template DNA binding assays [1,2], and were composed of $10 \mathrm{mM}$ Tris and $5 \mathrm{mM} \mathrm{MgCl}$ with $300 \mathrm{mM} \mathrm{KCl}$ for Klenow and $75 \mathrm{mM} \mathrm{KCl}$ for Klentaq. The $\mathrm{pH}$ was adjusted to $\mathrm{pH} 7.9$ at the temperature for each experiment. The assayed temperatures ranged from $5{ }^{\circ} \mathrm{C}$ to $70{ }^{\circ} \mathrm{C}$ for Klentaq, and from $5{ }^{\circ} \mathrm{C}$ to $45{ }^{\circ} \mathrm{C}$ for Klenow. The assayed incubation times were from 0 to $10 \mathrm{~min}$ for both polymerases. Timepoint data were collected in triplicate, and steady state rates $\left(\mathrm{k}_{\mathrm{ss}}\right)$ of incorporation were obtained by linear regression analysis using the program Kaleidagraph (Synergy Software).

\subsection{Other buffer systems}

Temperature dependence of Klentaq polymerase activity was also measured in a variety of different $10 \mathrm{mM}$ buffer solutions using a 2 minute incubation.

\subsection{Eyring analysis}

The steady state rates of nucleotide incorporation for Klentaq from $25{ }^{\circ} \mathrm{C}$ to $70{ }^{\circ} \mathrm{C}$ were analyzed using an Eyring plot (ln $\mathrm{k} / \mathrm{T}$ vs. $1 / \mathrm{T}$ ), and fit to a non-linear form of the Eyring equation [9]:

$$
\ln \mathrm{k}_{\mathrm{ss}} / \mathrm{T}=-\Delta \mathrm{H}^{\ddagger} / \mathrm{R} * 1 / \mathrm{T}+\left(\ln \mathrm{k}_{\mathrm{B}} / \mathrm{h}+\Delta \mathrm{S}^{\ddagger} / \mathrm{R}\right)
$$

where:

$\Delta \mathrm{H}^{\ddagger}($ at $\mathrm{T})=\Delta \mathrm{Hr}^{\ddagger}+\Delta \mathrm{Cp}^{\ddagger} *(\mathrm{~T}-\mathrm{Tr})$, and

$\Delta \mathrm{S}^{\ddagger}($ at $\mathrm{T})=\Delta \mathrm{Sr}^{\ddagger}+\Delta \mathrm{Cp}^{\ddagger} * \ln (\mathrm{T} / \mathrm{Tr})$, and

$\mathrm{k}_{\mathrm{B}} / \mathrm{h}$ is Boltzman's constant/Planck's constant.

The subscript ' $r$ ' denotes a single selected reference temperature in Kelvin while $\mathrm{T}$ is any other measured temperature. The activation enthalpy $\left(\Delta \mathrm{H}^{\ddagger}\right)$ and activation entropy $\left(\Delta \mathrm{S}^{\ddagger}\right)$ at any assayed temperature can then be extracted from the curve fit, and the free energy of activation $\left(\Delta \mathrm{G}^{\ddagger}\right)$ at each assayed temperature can be calculated $\left(\Delta \mathrm{G}^{\ddagger}=\right.$ $\left.\Delta \mathrm{H}^{\ddagger}-\mathrm{T} \Delta \mathrm{S}^{\ddagger}\right)$ or obtained directly from $\mathrm{k}_{\mathrm{ss}}=\mathrm{k}_{\mathrm{B}} \mathrm{T} / \mathrm{h} * \exp \left(-\Delta \mathrm{G}^{\ddagger} / \mathrm{RT}\right)$. Non-linear analysis was done with the program Kaleidagraph (Synergy Software).

\section{Results}

We have examined the temperature dependence of nucleotide incorporation for Klenow and Klentaq polymerases, with the purpose of comparing these results with their previously reported temperature dependences of initial primer-template (pt-DNA) binding [1,2]. The substrate for nucleotide incorporation was single-stranded M13 DNA primed with the same single-stranded 63mer used in binding studies, such that the sequence at the primer-template junction is the same in both the binding and incorporation assays.

Nucleotide incorporation activity was followed using $\left[\alpha-{ }^{32} \mathrm{P}\right] \mathrm{dATP}$, and steady state kinetic data are shown in Fig. 1. Polymerase nucleotide incorporation rates are often determined from a single timepoint: a strategy that will yield equivalent results if the reactions all remain in the initial linear kinetic phase at that timepoint under all conditions. Polymerase incorporation kinetics often switch to a second, slower rate at times longer than approximately 5-10 min, depending on temperature ([10-13], and data not shown). Due to the wide range of temperatures examined in this study, we collected data as a function of time to ensure that data compared across temperatures are all in the initial steady state kinetic phase. The kinetics are linear rather 

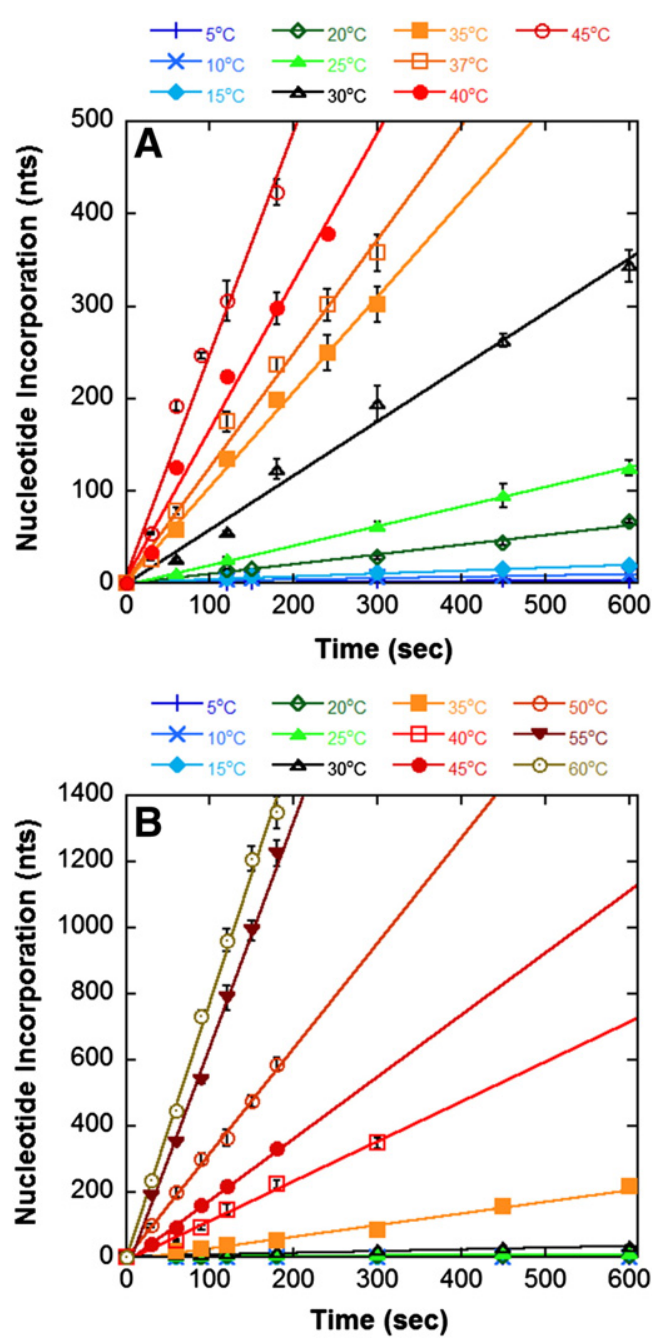

Fig. 1. Nucleotide incorporation kinetics of Klenow and Klentaq as a function of temperature. Panel A shows nucleotide incorporation for Klenow from 5 to $45{ }^{\circ} \mathrm{C}$. Panel B shows incorporation activity of Klentaq from 5 to $60^{\circ} \mathrm{C}$. The data are fit to a linear equation. Each data point is an average of three measurements, and the error bars show the standard deviation of the triplicates. For both polymerases, incorporation rates increase with the rise in temperature up to $45^{\circ} \mathrm{C}$ for Klenow and $60{ }^{\circ} \mathrm{C}$ for Klentaq. After $60{ }^{\circ} \mathrm{C}$, the incorporation rate for Klentaq decreases with increasing temperature. Data were not collected above $45^{\circ} \mathrm{C}$ for Klenow due to known onset of protein denaturation near this temperature.

than exponential in these experiments because a high enzyme:DNA ratio is used, making the reactions pseudo-zero order. A linear plot of [product] or [reactant] versus time is a classic diagnostic for zero order kinetics [14].

The nucleotide incorporation rates of Klenow and Klentaq were determined at five-degree intervals as shown in Fig. 2. For both polymerases, the rate of nucleotide incorporation is negligible at lower temperatures, then appears to switch "on" and increase with temperature. Data for Klentaq additionally show a maximal incorporation rate at $60{ }^{\circ} \mathrm{C}$ under these conditions, after which the incorporation rate declines. Klentaq does not begin to denature until above $95{ }^{\circ} \mathrm{C}$ [15], and the 63mer used to prime the DNA does not begin melting until above $70{ }^{\circ} \mathrm{C}$ under these buffer conditions (data not shown), thus the decreased nucleotide incorporation rate above $60{ }^{\circ} \mathrm{C}$ is not due to either protein unfolding or DNA denaturation. Klenow data were not collected past $45^{\circ} \mathrm{C}$, as the protein is known to begin to denature above this temperature $[15,16]$.

Previous binding studies have provided Gibbs-Helmholtz plots $(\Delta \mathrm{G}$ versus T) for pt-DNA binding of the two polymerases [1,2], and in Fig. 3 the $\Delta \mathrm{G}, \Delta \mathrm{H}$, and $\mathrm{T} \Delta \mathrm{S}$ data from those studies are shown superimposed

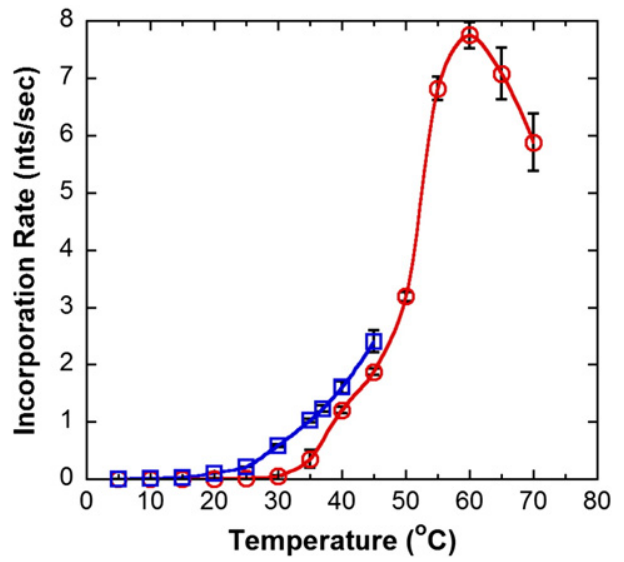

Fig. 2. Incorporation rates vs. temperature for Klenow and Klentaq polymerases. Rates are shown in nucleotides (nts) incorporated per second. Rates were obtained from the linear regression analyses of the data in Fig. 1, and error bars show the errors of the fits from Fig. 1. Incorporation activity rises above $1 \%$ of maximum at $15{ }^{\circ} \mathrm{C}$ for Klenow (open squares) and at $30{ }^{\circ} \mathrm{C}$ for Klentaq (open circles). For Klentaq, the activity reaches a maximum at $60{ }^{\circ} \mathrm{C}$ and then decreases with further increase in temperature.

with the temperature dependent nucleotide incorporation rate data from Fig. 2. These earlier binding studies showed that the $\Delta G$ of binding versus temperature for both polymerases is non-linear, with a minimum (tightest binding) near $47^{\circ} \mathrm{C}$ for Klentaq and near $33^{\circ} \mathrm{C}$ for Klenow (dashed lines in each panel of Fig. 3 ). A non-linear $\Delta \mathrm{G}$ versus temperature indicates that the binding reaction proceeds with a significant change in heat capacity, and this is reflected in the significant temperature dependencies of both $\Delta \mathrm{H}$ (solid diagonal lines in both panels) and $\mathrm{T} \Delta \mathrm{S}$ (dotted diagonal lines). For both polymerases, enthalpy and entropy both proceed from positive values at lower temperatures (where binding will be entropy driven) to negative values at higher temperatures (where binding will be enthalpy driven). The temperature points where enthalpy and entropy cross zero and change signs are denoted $\mathrm{T}_{\mathrm{H}}$ and $\mathrm{T}_{\mathrm{S}}$, respectively.

It can be seen in Fig. 3 that the apparent onset of the enzymatic activity corresponds to where the enthalpy of DNA binding switches signs (and favorability). In other words, nucleotide incorporation is almost negligible ( $<1 \%$ of maximum) until the temperature where $\Delta \mathrm{H}$ switches from positive to negative $\left(\mathrm{T}_{\mathrm{H}}\right)$. This temperature is $15{ }^{\circ} \mathrm{C}$ for Klenow and $30{ }^{\circ} \mathrm{C}$ for Klentaq. Note that the enzymes are never really predicted to completely "switch off" - they should continue to decrease exponentially in activity as the temperature decreases, but from a physiological point of view, in most situations, $<1 \%$ activity is effectively "off".

Nucleotide incorporation activity is sensitive to a variety of solution conditions, including but not limited to $\mathrm{pH}, \mathrm{KCl}$ concentration, $\mathrm{MgCl}_{2}$ concentration, and the nature of the DNA substrate $[17,18]$. Fig. 4 shows the temperature dependence of nucleotide incorporation under a variety of different solution conditions. It can be seen that different solution conditions can shift the temperature for maximal activity of the polymerase by up to about $10{ }^{\circ} \mathrm{C}$. The incorporation rates are normalized in Fig. 4 to emphasize transitions in the activity (onset of significant activity and temperature of maximum activity) the absolute rates at the temperature maxima vary significantly among the different conditions. The normalized data show that changing solution conditions alters the shape and steepness of the temperature dependence for activity. Interestingly, however, the temperature where enzymatic activity rises above $1 \%$ of maximum is nearly identical under all of the conditions examined, meaning that the correspondence of $\mathrm{T}_{\mathrm{H}}$ and rise in activity shown for the carefully matched buffer conditions in Fig. 3, would still hold for the wide variety of buffer conditions examined in Fig. 4. It is also notable that for all conditions the rise in activity tapers off or even reverses at higher temperatures. This non-Arrhenius behavior has several possible origins (see Discussion). 

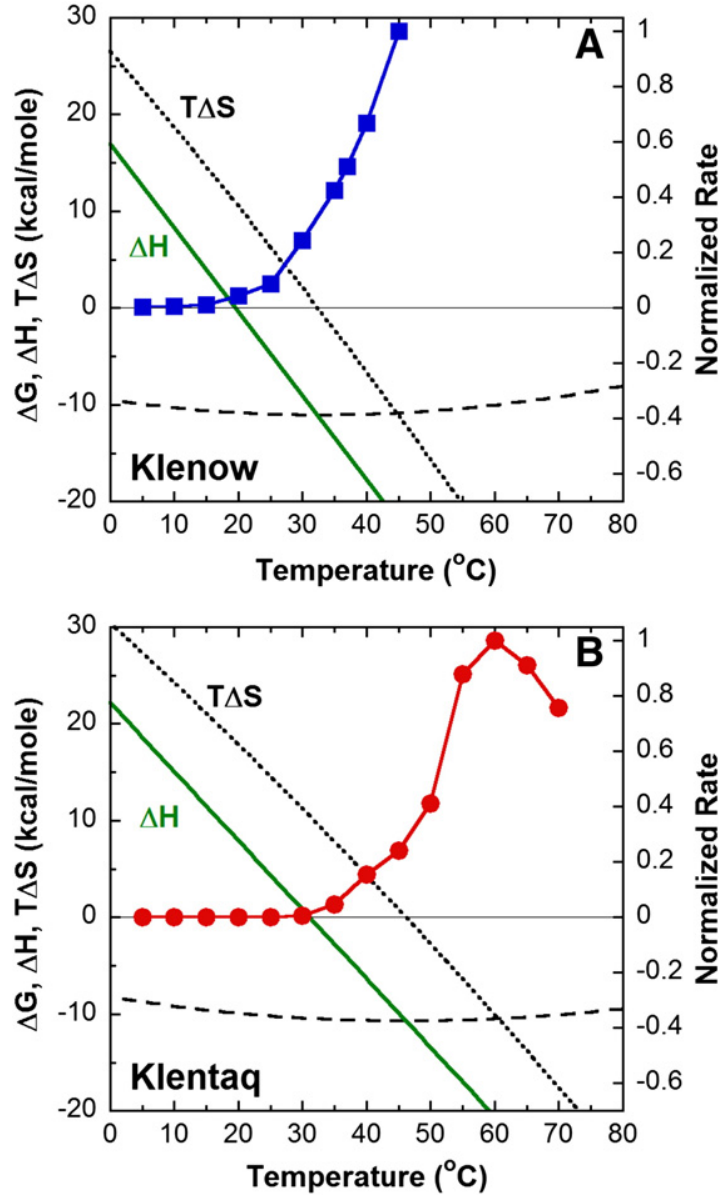

Fig. 3. Combined plots of polymerase-DNA binding thermodynamics and normalized polymerase activity of Klenow and Klentaq from Fig. 2. The thermodynamic binding data are from Refs. [1] and [2]. Nucleotide incorporation rate data are shown as closed squares for Klenow (panel A) and closed circles for Klentaq (panel B). The previous binding studies provided $\Delta \mathrm{G}, \Delta \mathrm{H}$, and $\mathrm{T} \Delta \mathrm{S}$, of binding, which are shown as dashed $(\Delta \mathrm{G})$, solid diagonal $(\Delta \mathrm{H})$, and dotted diagonal $(\mathrm{T} \Delta \mathrm{S})$ lines in both panels.

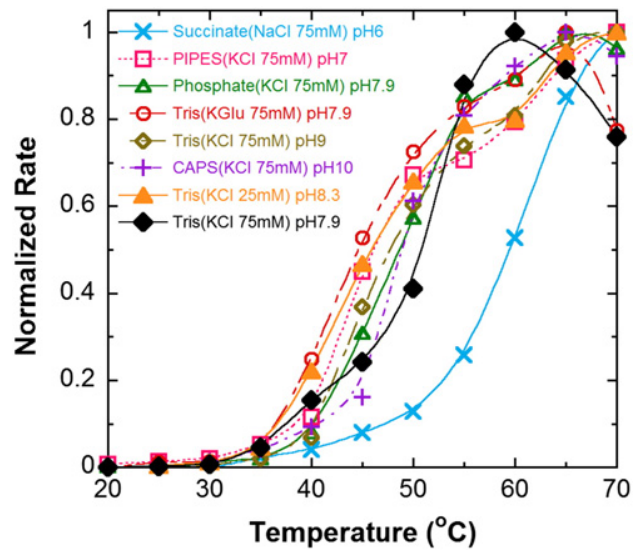

Fig. 4. Temperature dependence of the nucleotide incorporation activity of Klentaq in various buffer systems. Incorporation activities in this plot were measured at 2-min of incubation and then normalized. The different buffer systems examined are as follows: 1) X symbols: $10 \mathrm{mM}$ succinate, $75 \mathrm{mM} \mathrm{NaCl}, 5 \mathrm{mM} \mathrm{MgCl}_{2}, \mathrm{pH} 6$; 2) open squares: $10 \mathrm{mM}$ PIPES, $75 \mathrm{mM} \mathrm{KCl}, 5 \mathrm{mM} \mathrm{MgCl} 2, \mathrm{pH} 7$; 3) open triangles: $10 \mathrm{mM}$ phosphate, $75 \mathrm{mM} \mathrm{KCl}, 5 \mathrm{mM} \mathrm{MgCl}_{2}$, pH 7.9; 4) open circles: $10 \mathrm{mM}$ Tris, $75 \mathrm{mM}$ KGlutamate, $5 \mathrm{mM} \mathrm{MgCl}$, pH 7.9; 5) open diamonds: $10 \mathrm{mM}$ Tris, $75 \mathrm{mM} \mathrm{KCl,} 5 \mathrm{mM}$ $\mathrm{MgCl}_{2}, \mathrm{pH}$ 9; 6) plus symbols: $10 \mathrm{mM} \mathrm{CAPS}, 75 \mathrm{mM} \mathrm{KCl}, 5 \mathrm{mM} \mathrm{MgCl} 2, \mathrm{pH} 10$; and 7) closed triangles: $25 \mathrm{mM}$ Tris, $25 \mathrm{mM} \mathrm{KCl}, 4.5 \mathrm{mM} \mathrm{MgCl}_{2}, \mathrm{pH} 8.3$ (buffer condition \# 7 is from Ref. [13], others are designed to explore a range of pH's and to examine conditions analogous to several commercial PCR buffer conditions). The normalized incorporation rate data from Fig. 2 is shown as the closed diamonds.
Eyring analysis of the Klentaq kinetic data from Fig. 2 is shown in Fig. 5. Because the activity rate goes through a maximum after which it begins to slow with increasing temperature, the data are non-linear in both Eyring and Arrhenius plots. Eyring analysis can be expanded (by analogy to non-linear Gibbs-Helmholtz plots) to account for such non-linear temperature dependence [9]. Because the kinetic data (in Fig. 1) are pseudo-zero order, the rate $=\mathrm{k}_{\mathrm{ss}}$ (the rate constant) [14], for use in the Eyring analysis. Fersht and associates have previously used such expanded Eyring analyses to explain how a protein folding reaction can show a rate maximum, when Arrhenius theory predicts that the folding rate should increase continuously with temperature without going through a maximum [9]. Non-linear Eyring analysis provides quasi-thermodynamic information about the activated complex of a kinetic reaction: including the $\Delta \mathrm{G}^{\ddagger}, \Delta \mathrm{H}^{\ddagger}, \Delta \mathrm{S}^{\ddagger}$, and the $\Delta C \mathrm{p}^{\ddagger}$ of activation [9,19]. Fig. 5 shows that an analogous analysis can be applied to examine the enzymatic activity maximum that is observed for Klentaq at $60{ }^{\circ} \mathrm{C}$. The fitted $\Delta \mathrm{C} \mathrm{p}^{\ddagger}$ of activation for formation of the Klentaq-DNA-dNTP transition state complex is $-1.71 \pm 0.15 \mathrm{kcal} /$ molK, which is approximately $2 \times$ larger than the $\Delta \mathrm{Cp}$ of DNA binding itself [1]. Fig. 5 shows the Eyring plot for the data of Fig. 2, used to obtain the $\Delta \mathrm{Cp}^{\ddagger}$, along with the temperature dependencies of $\Delta \mathrm{G}^{\ddagger}, \Delta \mathrm{H}^{\ddagger}$ and $\mathrm{T} \Delta \mathrm{S}^{\ddagger}$ calculated as described in Materials and methods. Klenow does not exhibit such an activity maximum, instead its activity increases with temperature until the protein denatures. The $60{ }^{\circ} \mathrm{C}$ maximal activity temperature for Klentaq in Fig. 2 occurs long before either the protein or the DNA begins denaturing under those solution conditions [15].

While most chemical reactions normally exhibit a positive enthalpy of activation $\left(\Delta \mathrm{H}^{\ddagger}\right)$, when the reaction also has a $\Delta \mathrm{Cp}^{\ddagger}$, the $\Delta \mathrm{H}^{\ddagger}$ will change with temperature, and at higher temperatures will cross zero and become negative, as shown in Fig. 5. It is at this $\mathrm{T}_{\mathrm{H}}^{t}$ temperature that the enzyme activity begins to decline with increasing temperature, as dictated by the Gibbs-Helmholtz based extension of the Eyring equation (see Materials and methods). Thus, not only is the $\mathrm{T}_{\mathrm{H}}$ for the enthalpy of binding serving as an onset point for enzymatic activity, but also the quasi-thermodynamic $\Delta \mathrm{Cp}^{\ddagger}$ for the formation of the activated complex means that there will be a $\mathrm{T}_{\mathrm{H}}^{\dagger}$ for the enthalpy of activation corresponding to the reversal of the temperature dependence of nucleotide incorporation.

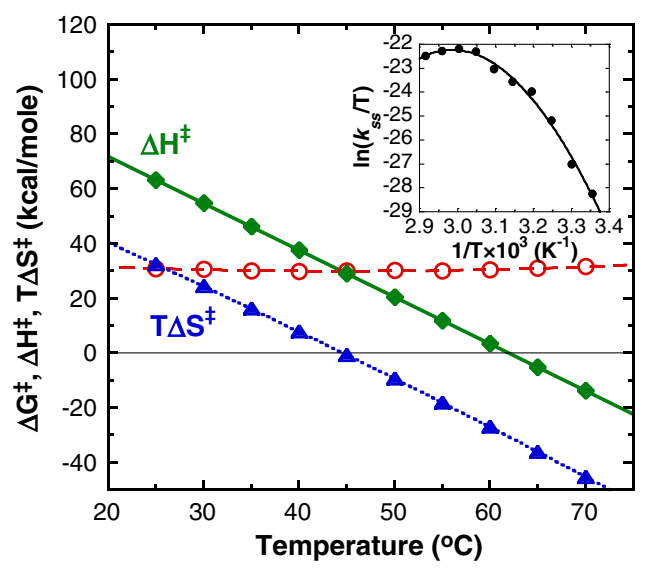

Fig. 5. The inset shows the Eyring plot of the temperature dependence of $\mathrm{k}_{\mathrm{ss}}$ for Klentac from $25{ }^{\circ} \mathrm{C}$ to $70{ }^{\circ} \mathrm{C}$. The Eyring plot is non-linearly analyzed as described in Materials and methods to obtain the fitted line and the heat capacity of activation $\left(\Delta \mathrm{Cp} \mathrm{p}^{\ddagger}\right.$ between the reactants and the transition state). The activation free energy ( $\Delta \mathrm{G}^{\ddagger}$, open circles), activation enthalpy ( $\Delta \mathrm{H}^{\ddagger}$, closed diamonds), and activation entropy (T $\Delta \mathrm{S}^{\ddagger}$, closed triangles) are calculated at each temperature, and these are shown in the main plot. Klentaq shows a gently curved activation free energy versus temperature dependence (open circles, $\Delta \mathrm{G}^{\ddagger}=29-31 \mathrm{kcal} / \mathrm{mol}$ across the temperature range) which is maintained by enthalpy-entropy compensation (large changes in $\Delta \mathrm{H}^{\ddagger}$ and $\mathrm{T} \Delta \mathrm{S}^{\ddagger}$ across the temperature range). 


\section{Discussion}

The purpose of this study was both to characterize the temperature dependence of the enzymatic activities of Klenow and Klentaq DNA polymerases, and to begin to ask the question of how the thermodynamics of DNA binding might potentially influence the overall activity of Klenow and Klentaq DNA polymerases. Typically, binding thermodynamics and enzymatic activity are examined independently for any enzyme, usually by different researchers, rather than being studied in parallel to ask how they might be energetically related. Herein we find that the temperature dependent shift in the enthalpy-entropy balance of initial DNA binding corresponds with specific changes in the overall functional behavior of the polymerases.

Both polymerases are tightly bound to DNA ( $\Delta \mathrm{G}$ tighter than $-9 \mathrm{kcal} / \mathrm{mole}$ ) at temperatures well below where their enzymatic activity initiates. Simple DNA binding with a negative $\Delta G$ is not sufficient for polymerase activity. Polymerase activity does not correlate with any trend in $\Delta G$ of binding, instead, the specific combination of enthalpy and entropy that produce the $\Delta \mathrm{G}$ of binding appears to correlate with the catalytic activity of the polymerases. Nucleotide incorporation activity does not rise above $1 \%$ until the binding enthalpy begins to turn negative, and physiologically relevant enzymatic activity increases as the favorable enthalpy gets larger. In the earlier thermodynamic binding studies of these polymerases we questioned whether there might be such a correspondence [2], and herein have been able to obtain appropriate enzymatic data to establish that there is.

It is possible that these matched $\mathrm{T}_{\mathrm{H}}$ /activity onset temperatures are just fortuitous, but the fact that the corresponding temperatures for Klentaq and Klenow differ by $15{ }^{\circ} \mathrm{C}$ argues against a simple coincidence, and also indicates that polymerase catalysis does not simply initiate at some universal start temperature, but actually does track individually for the two different enzymes.

The characteristic enthalpy-entropy compensation pattern for protein-DNA interactions (as illustrated by the parallel $\Delta \mathrm{H}$ and $\mathrm{T} \Delta \mathrm{S}$ dependencies in Fig. 3), which is also seen for other biomolecular interactions with associated heat capacity changes, has been observed and its meaning debated for many years (e.g. [3-6]). One widely recognized consequence of enthalpy-entropy compensation is that the $\Delta \mathrm{G}$ of binding remains relatively constant versus temperature (as also illustrated in Fig. 3). This study seems to be the first to suggest a new possible physiological utility of such a thermodynamic pattern: if an enzyme is effectively inactive (from a physiological point of view) when the enthalpy of substrate binding is positive, and active when the enthalpy of substrate binding is negative, then the thermodynamics of binding will serve as a sensitive means for regulating the activity of that enzyme.

This is not the first time that the specific $\Delta H$ versus $\mathrm{T} \Delta \mathrm{S}$ makeup of a $\Delta G$ has been proposed to be critical for manifesting a specific molecular/physiological function. Recent examples include the specific use of enthalpy, rather than simply $\Delta G$, to drive heterotropic regulation in the biotin repressor [20], and the finding that the specific enthalpy-entropy ratio for similar or identical binding free energies can dramatically alter the efficacy of HIV drugs (e.g. [21-23]).

The data in this study also question the longstanding concept of "corresponding states" of thermophilic and mesophilic proteins, which posits that the function of thermophilic proteins is inhibited at lower temperatures because they are too rigid [24,25]. The Klenow and Klentaq activity data in this study suggest that the situation is more complicated, as both proteins bind DNA quite tightly at low temperatures (i.e. there is no temperature dependent inhibition of the binding function of the thermophile at lower temperatures). Instead, the binding profiles are very similar for the two proteins versus temperature [1,2], while the up-shift temperature for enzymatic activity in the thermophile appears more closely correlated with the binding enthalpy rather than any characteristic of the protein's thermal stability $[15,16]$. It is, of course, possible that the DNA binding enthalpy (rather than binding free energy) is somehow correlated with protein rigidity, but the data of this study do not address this possibility.

Regarding the temperature maximum in the nucleotide incorporation rate, standard Arrhenius/Eyring theory holds that a reaction rate will always increase with increasing temperature. The rate maximum (and subsequent decrease in rate with further increase in temperature) exhibited by Taq polymerase is thus somewhat unusual, but is one of a slowly growing number of examples of such behavior in biochemistry. There have been a few different approaches to the analysis and interpretation of such non-linear Arrhenius/Eyring behavior. Winzor and Jackson caution that this can often be a result of a change in reaction mechanism or involvement of a new thermodynamic linkage at high temperatures (such as temperature dependent linkages to ion or proton binding) [26]. Such potential unforeseen linkages are almost impossible to completely rule out. In another approach, Daniel and Danson $[27,28]$ have postulated that such effects can occur if there is a pre-existing equilibrium between two different protein conformers. If this pre-existing equilibrium shifts with temperature, it can produce an effective reversal of enzyme behavior under conditions where one would normally expect continued acceleration of the reaction (e.g. increased temperature, increased [substrate], and such). In yet another approach to interpreting such a temperature maximum, Alan Fersht analyzed such Eyring plot curvature in a protein folding reaction by introducing a heat capacity of activation $\left(\Delta C \mathrm{p}^{\ddagger}\right)[9]$, by analogy to analysis of non-linear van't Hoff or GibbsHelmholtz plots. Application of such an approach to the analysis of the temperature maximum for Klentaq activity suggests that there exists a significant $\Delta \mathrm{Cp}^{\ddagger}$ of activated complex formation $(2 \times$ that of direct binding [1]), suggesting large changes in structure or hydration in the activated complex relative to the DNA-protein binary complex, and resulting in another enthalpic correlation: as shown in Fig. 5, the temperature where the activation enthalpy crosses zero ( $\mathrm{T}_{\mathrm{H}}^{*}$ ) correlates with the maximal activity temperature. Because there are several other potential explanations for non-linear Eyring behavior (e.g. [26-28]), this $\Delta \mathrm{Cp}^{\ddagger}$ induced correlation between $\mathrm{T}_{\mathrm{H}}^{\ddagger}$ and the activity maximum correlation might normally be discounted, but when considered alongside the binding enthalpy correlation $\left(\mathrm{T}_{\mathrm{H}}\right.$ and activity onset) it suggests another intriguing enthalpy based control point for enzymatic activity.

Biomacromolecules display a number of strategies for creating effective "on/off switches". Examples include homotropic and heterotropic allostery, two-state protein unfolding, and covalent modifications such as phosphorylation. These data give a glimpse into another potential type of molecular on/off switch that takes advantage of the fact that many biomolecular interactions (i.e. all those with heat capacity changes) display enthalpy-entropy compensation with large excursions of $\Delta \mathrm{H}$ and $\mathrm{T} \Delta \mathrm{S}$. The physiological utility of such a thermodynamic based "on/off" switch in the case of the DNA polymerases examined here is that both polymerases will stay bound to DNA (with a strongly negative $\Delta \mathrm{G}$ ) even at low, suboptimal growth temperatures, where it would not be advantageous to replicate the DNA, but then will increase to physiologically useful nucleotide incorporation rates at temperatures more favorable for growth.

Immediate questions begged by these data are: what molecular events correlate with the $T_{H}$ transition (and the $T_{H}^{t}$ transition), and how might they translate into catalytic rate changes? Probably the biggest obstacle in attempting to answer such questions is the fact that the underlying molecular origins of the heat capacity of binding and the temperature dependencies of the enthalpy and entropy themselves are not yet understood. In other words, as mentioned above, the molecular origins for the existence of $\mathrm{T}_{\mathrm{H}}$ and $\mathrm{T}_{\mathrm{S}}$, and the parallel $\Delta \mathrm{H}$ and $\mathrm{T} \Delta \mathrm{S}$ plots for binding (denoted enthalpy-entropy compensation), continue to be debated (e.g. [3-6]). Thus, understanding the molecular origins of these underlying thermodynamics (i.e. what bonds are made/broken, strengthened/weakened) is required before we can begin to truly understand what might be happening at the 
molecular level at $\mathrm{T}_{\mathrm{H}}$ to "switch on" catalysis. Perhaps upshift of enzymatic activity is not even specifically dependent on specific changes in non-covalent bonding that cause enthalpy-entropy compensation and manifest $\mathrm{T}_{\mathrm{H}}$, but simply requires a little internal heat, a secondary effect generated by a negative enthalpy. In addition, a crucial question is simply asking whether $\mathrm{T}_{\mathrm{H}}$ /activity correlations, i.e. the patterns depicted in Fig. 3, are general for other enzymes, or whether they are simply correlations for these two polymerases. Currently, the thermodynamic plus enzymatic activity data presented herein are the only existing data sets for any enzyme system where such a comparison can be made.

\section{Acknowledgements}

The authors thank the Michael Doughty lab at Southeastern Louisiana University for initial advice on the nucleotide incorporation assay. This work was supported by the National Science Foundation.

\section{References}

[1] K. Datta, V.J. LiCata, Thermodynamics of the binding of Thermus aquaticus DNA polymerase to primed-template DNA, Nucleic Acids Res. 31 (2003) 5590-5597.

[2] K. Datta, A.J. Wowor, A.J. Richard, V.J. LiCata, Temperature dependence and thermodynamics of Klenow polymerase binding to primed-template DNA, Biophys. J. 90 (2006) 1739-1751.

[3] R. Lumry, S. Rajender, Enthalpy-entropy compensation phenomena in water solutions of proteins and small molecules: a ubiquitous property of water, Biopolymers 9 (1970) 1125-1227.

[4] A. Cooper, Thermodynamic analysis of biomolecular interactions, Curr. Opin. Chem. Biol. 3 (1999) 557-563.

[5] L. Jen-Jacobson, L.E. Engler, J.T. Ames, M.R. Kurpiewski, A. Grigorescu, Thermodynamic parameters of specific and nonspecific protein-DNA binding, Supramol. Chem. 12 (2000) 143-160.

[6] M.R. Eftink, A.C. Anusiem, R.L. Biltonen, Enthalpy-entropy compensation and heat-capacity changes for protein-ligand interactions - general thermodynamic models and data for the binding of nucleotides to ribonuclease-A, Biochemistry 22 (1983) 3884-3896.

[7] K. Datta, V.J. LiCata, Salt dependence of DNA binding by Thermus aquaticus and Escherichia coli DNA polymerases, J. Biol. Chem. 278 (2003) 5694-5701.

[8] F.R. Bryant, K.A. Johnson, S.J. Benkovic, Elementary steps in the DNA polymerase I reaction pathway, Biochemistry 22 (1983) 3537-3546.

[9] M. Oliveberg, Y.-J. Tan, A.R. Fersht, Negative activation enthalpies in the kinetics of protein folding, Proc. Natl. Acad. Sci. U. S. A. 92 (1995) 8926-8929.
[10] S.J. Benkovic, C.E. Cameron, Kinetic analysis of nucleotide incorporation and misincorporation by Klenow fragment of Escherichia coli DNA polymerase I, Methods Enzymol. 262 (1995) 257-269.

[11] H.E. Huber, S. Tabor, C.C. Richardson, Escherichia coli thioredoxin stabilizes complexes of bacteriophage T7 DNA polymerase and primed templates, J. Biol. Chem. 262 (1987) 16224-16232.

[12] J.K. Kumar, S. Tabor, C.C. Richardson, Role of the C-terminal residue of the DNA polymerase of bacteriophage T7, J. Biol. Chem. 276 (2001) 34905-34912.

[13] W.R. McClure, T.M. Jovin, The steady state kinetic parameters and non-processivity of Escherichia coli deoxyribonucleic acid polymerase I, J. Biol. Chem. 250 (1975) 4073-4080.

[14] J.I. Steinfeld, J.S. Francisco, W.L. Hase, Chemical Kinetics and Dynamics, Prentice-Hall, New Jersey, 1989. 6.

[15] I. Karantzeni, C. Ruiz, C.C. Liu, V.J. LiCata, Comparative thermal denaturation of Thermus aquaticus and Escherichia coli type 1 DNA polymerases, Biochem. J. 374 (2003) 785-792.

[16] A.J. Richard, C.C. Liu, A.L. Klinger, M.J. Todd, T.M. Mezzasalma, V.J. LiCata, Thermal stability landscape for Klenow DNA polymerase as a function of pH and salt concentration, Biochim. Biophys. Acta, Protein Proteomics 1764 (2006) 1546-1552.

[17] F.C. Lawyer, S. Stoffel, R.K. Saiki, S.Y. Chang, P.A. Landre, R.D. Abramson, D.H. Gelfand, High-level expression, purification, and enzymatic characterization of full-length Thermus aquaticus DNA polymerase and a truncated form deficient in 5' to 3' exonuclease activity, PCR Methods Appl. 2 (1993) 275-287.

[18] J.W. Brandis, S.G. Edwards, K.A. Johnson, Slow rate of phosphodiester bond formation accounts for the strong bias that Taq DNA polymerase shows against 2',3'-dideoxynucleotide terminators, Biochemistry 35 (1996) 2189-2200.

[19] D. Eisenberg, D. Crothers, Physical Chemistry with Applications to the Life Sciences, Benjamin/Cummings, Menlo Park, California, 1979. 242-243.

[20] P.H. Brown, D. Beckett, Use of binding enthalpy to drive an allosteric transition, Biochemistry 44 (2005) 3112-3121.

[21] E. Freire, Do enthalpy and entropy distinguish first in class from best in class? Drug Discov. Today 13 (2008) 19-20.

[22] A. Schon, N. Madani, A.B. Smith, J.M. Lalonde, E. Freire, Some binding related drug properties are dependent on thermodynamic signature, Chem. Biol. Drug Des. 77 (2011) 161-165.

[23] J.E. Ladbury, G. Klebe, E. Freire, Adding calorimetric data to decision making in lead discovery: a hot tip, Nat. Rev. Drug Discov. 9 (2010) 23-27.

[24] R. Jaenicke, Protein stability and molecular adaptation to extreme conditions, Eur. J. Biochem. 202 (1991) 715-728.

[25] R. Jaenicke, G. Bohm, The stability of proteins in extreme environments, Curr. Opin. Struct. Biol. 8 (1998) 738-748.

[26] D.J. Winzor, C. Jackson, Interpretation of the temperature dependence of equilibrium and rate constants, J. Mol. Recognit. 19 (2006) 389-407.

[27] R.M. Daniel, M.J. Danson, R. Eisenthal, The temperature optima of enzymes: a new perspective on an old phenomenon, Trends Biochem. Sci. 26 (2001) 223-225.

[28] R.M. Daniel, M.J. Danson, A new understanding of how temperature affects the catalytic activity of enzymes, Trends Biochem. Sci. 35 (2010) 584-591. 